\title{
Centesimal composition and physicochemical parameters of meat from santa inês lambs fed with passion fruit peel ${ }^{1}$
}

\section{Composição centesimal e parâmetros físico-químicos da carne de cordeiros santa inês alimentados com casca de maracúja ${ }^{1}$}

\author{
Cristiane Leal dos Santos-Cruz ${ }^{2 *}$; Juan Ramon Olalquiaga Pérez; \\ Thiago Ramos Lima ${ }^{4}$; Christian Albert Carvalho da Cruz; \\ Braulio Crisanto Carvalho da Cruz ${ }^{6}$; Rodrigo Soares Junqueira ${ }^{7}$
}

\begin{abstract}
The objective was to determine the centesimal composition and some physicochemical parameters in the longissimus lumborum muscle from non castrated Santa Ines lambs, fed diets containing different proportions of passion fruit peel, in the following treatments: T1: 100\% elephant grass, T2: $90 \%$ elephant grass $+10 \%$ dried passion fruit peel, T3: $80 \%$ elephant grass $+20 \%$ dried passion fruit peel, T4: $70 \%$ elephant grass $+30 \%$ dried passion fruit peel based on the elephant grass natural matter. The inclusion of 30\% passion fruit peel in the diet of Santa Inez lambs turned the meat less intensely red $(\mathrm{a}=$ $7.40)$ but with a stronger hue $(\mathrm{h}=59.75)$ than that resulting from the $10 \%$ addition. The water retention capacity was higher in the meat of lambs fed $30 \%$ passion fruit peel, as well as, shear force $(0.50)$ and $\mathrm{pH}(6.40)$, but these values are adequate to assure quality. Protein content, minerals and energy did not change, but neither did their values fall below the level desired by industry. Lipid content was higher in the meat of lambs fed $20 \%$ of passion fruit peel. Therefore, the inclusion of $30 \%$ of passion fruit peel in the silage of growing Santa Inês lambs is recommended, because it improves the quality and nutritional parameters of the meat.
\end{abstract}

Key words: Alternative food, sheep, quality meat

\section{Resumo}

Objetivou-se determinar a composição centesimal e alguns parâmetros físico químicos no músculo Longissimus lumborum de 16 cordeiros Santa Inês, não castrados, alimentados com diferentes dietas contendo casca desidratada de maracujá, sendo os tratamentos T1: 100\% capim elefante; T2: $90 \%$ capim elefante $+10 \%$ casca desidratada de maracujá; T3: $80 \%$ capim elefante $+20 \%$ casca desidratada de maracujá; T4: $70 \%$ capim elefante $+30 \%$ casca desidratada de maracujá com base na matéria natural do capim elefante. A inclusão de $30 \%$ de casca desidratada de maracujá na dieta de cordeiros Santa

\footnotetext{
${ }^{1}$ Apoio UESB e Necttare Ltda.

2 Prof ${ }^{a}$ DSc., Universidade Estadual do Sudoeste da Bahia, UESB/DTRA/Unidade Experimental de Caprinos e Ovinos, Itapetinga, BA. E-mail: crislealcruz@gmail.com

${ }^{3}$ Prof. DSc., Universidade Federal de Lavras, UFLA/DZO/Setor de Ovinos, Lavras,MG. E-mail: jperez@dzo.ufla.br

${ }^{4}$ Discente, Universidade Estadual do Sudoeste da Bahia, UESB/Unidade Experimental de Caprinos e Ovinos. Bolsista FAPESB. Itapetinga, BA. E-mail: t.h.ago_18@hotmail.com

${ }_{5}^{5}$ Prof. M.e. e Discente de Doutorado UESB, IF Baiano, Itapetinga, BA. E-mail: christian.albert@hotmail.com

${ }^{6}$ Prof. Me. e Discente de Doutorado, Instituto Federal de Roraima, IF, Roraima, RR. E-mail: baucruz@hotmail.com

${ }^{7}$ Discente, UESB/Unidade Experimental de Caprinos e Ovinos, Bolsista PIBIC/CNPq. Itapetinga, BA. E-mail: rodrigoparmacte@ hotmail.com

* Author for correspondence
} 
Inês tornou a carne com um vermelho menos intenso $(a=7,40)$, mas com grau de tonalidade maior $(\mathrm{h}=59,75)$ em relação àquela com inclusão de $10 \%$. A capacidade de retenção de água foi maior na carne de cordeiros alimentados com $30 \%$ de casca desidratada de maracujá, assim como a força de cisalhamento $(0,50)$ e $\mathrm{pH}(6,40)$, porém são valores adequados para garantir a qualidade. Os teores de proteína, minerais e energia não se modificaram, mas também não apresentaram valores aquém do que é desejado pelas indústrias. Os teores de lipídios se apresentaram com maior quantidade na carne de cordeiros alimentados com $20 \%$ de casca desidratada de maracujá. Recomenda-se a inclusão de 30\% de casca desidratada de maracujá na silagem de cordeiros Santa Inês em crescimento, pois melhora os parâmetros de qualidade e nutricionais da carne.

Palavras-chave: Alimento alternativo, ovinos, qualidade de carne

\section{Introduction}

Lamb production can be improved in quality and profitability, using alternative feeding resources with good nutritional value, allowing positive changes in physicochemical composition of the meat. However, Gallo et al. (2009) call attention to the fact that composition values can vary according to the animal's condition, resulting in lower protein and water percentage, and high degree of fat.

Diaz et al. (2002) reported that the humidity of sheep meat varies between $61.32 \%$ and $69.08 \%$, which corresponds to a variation between $38.68 \%$ and $30.92 \%$ in the dry matter. The author also reported that crude protein and fat content in sheep meat varies between $18.45 \%$ and $20.25 \%$, and between $8.04 \%$ and $11.6 \%$, respectively, while ashes represent $0.98 \%$. However, these numbers can vary depending on various factors, among them, dietary composition (HOPKINS; HALL; CHANNON, 2001).

According to Pinheiro et al. (2010) meat quality can be assessed by its $\mathrm{pH}$, color, water retention capacity, tenderness and losses in cooking, and by its sanitary and nutritional aspects. Such characteristics can clearly show if the meat is of higher or lower quality, and the results can be used to determine the price of products that have different qualities and directed them to different types of market.

Meat quality parameters are important for commercialization and consumer acceptance, and some research studies involving sheep have been carried out to verify the influence of feeding
(TONETTO et al., 2004; MADRUGA et al., 2005; ASTIZ, 2008), however, studies are scarce and do not enable the confrontation of different situations and types of food.

Passion fruit peel can be an alternative in the production of sheep meat, because, according to Cruz et al. (2011), it is a residue whose dry matter has $13.4 \%$ crude protein; $2.9 \%$ ether extract; $9.9 \%$ of mineral matter; $59 \%$ of neutral detergent fiber; $49.2 \%$ acid detergent fiber and according to Lousada Junior et al. (2006), 52.98\% total digestible nutrients.

The objective was to determine the centesimal composition and physicochemical parameters of meat from Santa Inês lambs fed dried passion fruit peel, added to elephant grass silage at different proportions.

\section{Material and Methods}

The experiment was carried out at the center for sheep and goat Nutritional Assays, within the Department of Agricultural and Animal Technology of Universidade Estadual do Sudoeste da Bahia Uesb, at Itapetinga, Bahia.

Sixteen Santa Inês lambs, not castrated, with an average initial weight of $25 \mathrm{~kg}$ at 80 days old, chosen entirely at random, were used, submitted to four different silages containing elephant grass (Pennisetum purpureum, schum) and dried passion fruit peel (Passiflora edulins) - DPP, at the following proportions (treatments): T1: 100\% elephant grass; 
T2: $90 \%$ elephant grass $+10 \%$ DPP; T3, $80 \%$ elephant grass $+20 \%$ DPP; T4: 70\% elephant grass $+30 \%$ DPP, based on natural matter (NM). The diet concentrate composed of corn meal, soybean meal and mineral salt was formulated according to NRC (2006) for a daily weight gain of $200 \mathrm{~g}$, on an isoproteic diet with $13 \% \mathrm{CP}$. The diet (Table 1) was supplied daily at $7 \mathrm{am}$ and $4 \mathrm{pm}$ with an amount calculated to allow an excess of $10 \%$. The forage:concentrate ratio was 60:40.

Table 1. Percent (\% DM) and chemical $(\mathrm{g} / \mathrm{kg})$ composition of experimental diets.

\begin{tabular}{lcccc}
\hline & \multicolumn{4}{c}{ Passion fruit peel level (\%) } \\
\cline { 2 - 4 } Ingredient (\%) & $\mathbf{0}$ & $\mathbf{2 0}$ & $\mathbf{3 0}$ & $\mathbf{4 0}$ \\
\hline Dried passion fruit peel (\%) & 0.00 & 10.00 & 20.00 & 30.00 \\
Elephant grass (\%) & 60.00 & 50.00 & 40.00 & 30.00 \\
Ground corn (\%) & 25.80 & 25.90 & 26.60 & 27.00 \\
Soybean meal (\%) & 11.20 & 11.10 & 10.40 & 10.00 \\
Mineral mixture (\%) & 3.00 & 3.00 & 3.00 & 3.00 \\
\hline Chemical-bromatological composition (g/kg) & $(\mathbf{1 )})$ & & \\
\hline Dry matter & 48.13 & 51.92 & 54.65 & 56.82 \\
Crude protein & 13.90 & 15.70 & 16.90 & 14.30 \\
Mineral matter & 8.80 & 9.40 & 9.20 & 8.70 \\
Organic matter & 39.30 & 42.50 & 45.4 & 48.10 \\
Ether extract & 2.60 & 2.60 & 2.60 & 2.60 \\
Neutral detergent fiber & 60.59 & 53.85 & 55.35 & 52.44 \\
NDFcp ${ }^{(2)}$ & 50.20 & 39.70 & 36.90 & 33.90 \\
Total carbohydrates & 74.45 & 73.84 & 72.17 & 74.95 \\
Non-fibrous carbohydrates & 13.85 & 19.98 & 16.82 & 22.50 \\
Acid detergent fiber & 41.80 & 37.70 & 36.16 & 34.12 \\
Total digestible nutrients & 31.30 & 36.30 & 49.30 & 39.60 \\
\hline
\end{tabular}

${ }^{(1)}$ Assays carried out at the Forage Culture labs and at the sheep and goat Experimental Unit of Universidade Estadual do Sudoeste da Bahia - Uesb, Itapetinga campus, Bahia.

${ }^{(2)} \mathrm{NDF} c p$ : Neutral detergent fiber corrected for protein.

Source: Elaboration of the authors.

The passion fruit residue was kindly supplied by juice processing company Necttare Indústria e Comercio de Produtos Alimentícios Ltda, located in Feira de Santana, Bahia and dried on a cement patio in the company. The drying process consisted of exposing the material under the sun at an average temperature of $37^{\circ} \mathrm{C}$, and turning it four times a day for homogenization. At night, the peel was gathered and covered with black plastic and was scattered again in the morning. Drying was considered complete when the material achieved $85 \%$ DM, which took 6 days. The elephant grass came from a field already established in the Uesb campus at Itapetinga, Bahia, and was cut at 60 days of growth.
Thirty two 200-liter vats were used as experimental silos, to which $100 \mathrm{~kg}$ of forage was added, with a density of $500 \mathrm{~kg} / \mathrm{m}^{3}$. The material was weighed and homogenized according to the treatments, and was later pressed in the silos with the help of concrete tampers and human trampling. The silos were opened after 30 days.

The lambs were wormed and weighed at the beginning and the end of the experiment, and distributed at random in individual pens measuring $1.0 \times 1.5 \mathrm{~m}$ with freely available water. The experiment lasted 52 days, including 10 days for adaptation. 
The lambs were slaughtered according to RIISPOA (BRASIL, 1997), and the carcasses were refrigerated at $4{ }^{\circ} \mathrm{C} \pm 2{ }^{\circ} \mathrm{C}$ for 24 hours. Then, the longissimus lumborum muscles was removed, identified and stored at $-18^{\circ} \mathrm{C}$ for proximate composition (humidity, protein, total lipids, mineral matter and energy) and physicochemical parameters (color, water activity, $\mathrm{pH}$, water retention capacity, weight loss in cooking, and shear force) determination.

To determine humidity, we used a Master pair of scales model ID200 from Uesb's UECO laboratory of physicochemical assays, and duplicated $1 \mathrm{~g}$ samples submitted to $175^{\circ} \mathrm{C}$ for 20 minutes. Protein was quantified using the Micro - Kjeldahl method, which is based on determining total nitrogen and using a factor of 6.25 for conversion into protein. During digestion, as a result of sulfuric acid action, carbon is released as carbon dioxide and hydrogen as water. Nitrogen is turned into ammonia $\left(\mathrm{NH}_{3}\right)$ and fixed as ammoniacal salt (ammonia sulphate). During distillation, the concentrated sodium hydroxide solution releases ammonia, which is distilled, and then the digestion was titrated in a solution of sulphuric acid using analytical method n. 928.08 (AOAC, 2000).

Mineral matter was calculated using a method based on loss of weight after incineration at $500^{\circ}-550^{\circ} \mathrm{C}$ in muffle furnace with organic matter destruction and no considerable decomposition of mineral residue compounds or loss through volatilization (analytical method n. 920.153, AOAC, 2000). Total lipid content was determined by Soxhlet extraction, using 1.0 to $2.0 \mathrm{~g}$ of triplicate samples in natural matter. According to the methodology by Santos (2002) adapted from Silva (1981), the samples were packed with germitex paper and later partially defatted with ethyl ether in a hermetically sealed recipient. After 12 hours, they were removed from the recipient and taken to the stove at $105^{\circ} \mathrm{C}$ in order to obtain the dry weight of the partially defatted sample, and then taken to the Soxhlet extractor for residual fat. Total fat was obtained by adding partial and residual fat. Energy was estimated considering the caloric value of 1 gram of fat, which corresponds to 9 kcal.

Physicochemical parameters were also determined at Uesb's UECO (Experimental sheep and goat Unit) laboratory of physicochemical assays, always in duplicate. Water activity (aW) was found using a bench Aqualab equipment, as determined by Instituto Adolfo Lutz (1985).

To determine $\mathrm{pH}$, it was used a pHmeter (Digmed) in which a 50-g sample was mixed in a $200 \mathrm{ml}$ Becker, homogenized in Turrax with $10 \mathrm{ml}$ distilled water to allow penetration of the electrode. Before the assay, the pHmeter was adjusted with a pH 7 tamponade. After each assay, the electrode was cleaned with a potassium chloride solution, toilet paper, and then washed with distilled water while held with tweezers (INSTITUTO ADOLFO LUTZ, 1985).

Color results were expressed using the CIE $\mathrm{L}^{*} \mathrm{a} \mathrm{b}^{*}$ system, in which $\mathrm{L}^{*}$ measures the reflectance percentage, $\mathrm{a}^{*}$ measures variation from red to green and $b^{*}$ measures variation from yellow to blue; and the CIE $\mathrm{L}^{*} \mathrm{c}^{*} \mathrm{~h} *$ system, in which $\mathrm{L}^{*}$ (luminosity), $\mathrm{c}^{*}$ (chroma) and $\mathrm{h}$ (hue angle), using a Hunterlab Miniscan EZ colorimeter, model 4500 L. For the color reading, the muscles were defrosted and exposed to natural light and atmospheric gas mixtures for 30 minutes so as to return to their natural color, and then the reading procedure was carried out on the entire muscle, on a white polyethylene board, at a closed place, with little luminosity (INSTITUTO ADOLFO LUTZ, 1985).

Water retention capacity (WRC) was calculated using a centrifuge according to Nakamura and Katoh (1985), in which $1.0 \mathrm{~g}$ sample was weighed in filter paper and placed in the centrifuge for 4 minutes at $1500 \times \mathrm{G}$, then dried in a stove at $70^{\circ} \mathrm{C}$ for 12 hours.

For loss of weight in cooking (LWC), two meat pieces approximately $2.5 \mathrm{~cm}$ thick were used. The samples were weighed in semi analytical balances, roasted on a pre-heated hot plate at $150^{\circ} \mathrm{C}$. Once it 
reached $35^{\circ} \mathrm{C}$, the samples were turned and kept on the hot plate until their internal temperature reached $72^{\circ} \mathrm{C}$ (temperature was monitored with the help of a digital thermometer). Then, the samples were left at room temperature until cold, and weighed again. The difference between the sample's initial and final sample weight indicated the LWC (AMASA, 1978).

The texture or shear force was determined with a Brookfield CT3 Texture Analyzer with a Warner Bratzler slide, using samples from the loss of weight in cooking. The shear force was measured in a scale from zero to $10 \mathrm{kgf} / \mathrm{second}$, with the velocity varying from 5 millimeters/second $(\mathrm{mm} / \mathrm{s})$ to 10 $\mathrm{mm} / \mathrm{s}$. Cylinder shapes were cut in the direction of the muscle fibers. The cylinders were removed with the help of a drill coupled to a $1.5-\mathrm{cm}-$ diameter probe. The shear force (SF) was registered following the methodology of Johnson et al. (1989). The statistical analysis used SAS (2001).

\section{Results and Discussion}

Average daily weight gain had a linear increase of $112.0 ; 115.2 ; 129.6$ and $187.9 \mathrm{~g}$ /day for treatments with $0,10,20$ and $30 \%$ of dried passion fruit peel, respectively (Table 2). An improvement in the lambs' gain composition occurred probably due to the good composition of their diet, which contained elephant grass silage with $30 \%$ dried passion fruit peel. However, these values are below those determined by Azzalini and Ponzoni (1979), who indicated an average daily weight gain close to $270 \mathrm{~g}$ /day as being adequate for meat lambs. Nevertheless, the lambs used in this experiment are from females reared in a pasture breeding system, and genetics may be a factor for their weight gain not to have gone over $200 \mathrm{~g}$. But there was positive response to the inclusion of passion fruit peel in their diet.

Table 2. Initial body weight - IBW, final body weight - FBW, total weight gain - WG, average daily weight gain ADWG, Dry matter intake - DMI (g/animal/day; g/TMU $\mathrm{LW}^{0.75}$ ) and feed conversion - FC, in animals receiving elephant grass silages with increasing levels of dried passion fruit peel.

\begin{tabular}{lcccccc}
\hline \multirow{2}{*}{ Variables } & \multicolumn{9}{c}{ Levels of passion fruit peel addition (\%) } & \multirow{2}{*}{ Regression Equation } & \multirow{2}{*}{$\mathbf{R}^{2}$} \\
\cline { 2 - 5 } & $\mathbf{0}$ & $\mathbf{1 0}$ & $\mathbf{2 0}$ & $\mathbf{3 0}$ & & \\
\hline IBW & 24.7 & 24.5 & 25.8 & 25.5 & $\mathrm{y}^{\prime}=25.1$ & - \\
FBW & 30.7 & 30.7 & 32.8 & 35.7 & $\mathrm{y}^{\prime}=29.91+0.17 \mathrm{x}$ & 86.9 \\
WG kg & 6.0 & 6.2 & 7.0 & 10.1 & $\mathrm{y}^{\prime}=5.36+0.131 \mathrm{x}$ & 79.25 \\
ADWG g/day & 112.0 & 115.2 & 129.6 & 187.9 & $\mathrm{y}^{\prime}=99.86+2.42 \mathrm{x}$ & 78.29 \\
DMI g/day & 998.8 & 1070.0 & 1110.3 & 1350.2 & $\mathrm{y}^{\prime}=968.15+10.94 \mathrm{x}$ & 85.16 \\
DMI - LW & 81.8 & 88.5 & 87.8 & 103.1 & $\mathrm{y}^{\prime}=80.32+0.632 \mathrm{x}$ & 81.32 \\
FC & 8.9 & 9.2 & 8.6 & 7.2 & $\mathrm{y}^{\prime}=9.37-0.05 \mathrm{x}$ & 69.30 \\
\hline
\end{tabular}

Source: Elaboration of the authors.

The average daily weight gain observed in lambs fed $20 \%$ and $30 \%$ dried passion fruit peel was close to that found by Borges et al. (2004) in a study involving lambs fed diets formulated with different levels of dried cashew fruit pulp, with an average daily weight gain of 120.24 to $152.68 \mathrm{~g} /$ day. Andrade et al. (2001) also obtained low average daily weight gain, between 91.7 and $127.6 \mathrm{~g} /$ day, working with lambs of undefined breed, fed agroindustrial acerola, melon and pineapple residues at $30 \%$ of the total ration, in substitution of elephant grass.

Dry matter intake increased when Santa Inês lambs were fed silage containing dried passion fruit peel, that is, for each level of dry passion fruit peel addition, there was an increase of $10.9 \mathrm{~g} /$ day. 
Neiva et al. (2006) observed an increased intake of $1.29 \%$ in $\mathrm{g} / \mathrm{TMU}$, whereas for intake expressed in $\mathrm{g} /$ animal/day, there was a $19.4 \%$ increase for every $1 \%$ inclusion of dried passion fruit peel.

Feed conversion varied from 8.9 to 7.2 for treatments between 0 and $30 \%$ dried passion fruit peel and displayed a decreasing linear effect, that is, for each $1 \%$ of dried passion fruit peel added, there was a $0.05 \%$ decrease in feed conversion, increasing therefore the food efficiency of lambs fed the diet of $30 \%$ dried passion fruit peel added to the silage, explained by a weight gain of $187.9 \mathrm{~g} /$ day and intake of $1350.2 \mathrm{~g} /$ day for lambs submitted to this treatment. Borges et al. (2004) found similar results (6.49 to 9.83), however, the best feed conversion was obtained by Furusho, Pérez and Lima (1997), at 4.35 for Santa Inês lambs fed diets containing cashew fruit stalk.

The $\mathrm{pH}$ of longissimus lumborum varied from 5.8 to 6.04 as the level of dried passion fruit peel was increased (Table 3). The $\mathrm{pH}$ was determined from the diluted meat sample; however, like the final $\mathrm{pH}$ obtained at 24 hours post mortem, this value is also related with the quality of the meat to be consumed.

Table 3. Physicochemical and percentage composition of the longissimus lumborum muscles from Santa Inês lambs fed silage containing different levels of passion fruit peel.

\begin{tabular}{|c|c|c|c|c|c|c|}
\hline \multirow{2}{*}{ Variables } & \multicolumn{4}{|c|}{ Levels of Passion fruit peel (\%) } & \multirow{2}{*}{ Equation } & \multirow{2}{*}{$\mathbf{R}^{2}$} \\
\hline & $\mathbf{0}$ & 10 & 20 & 30 & & \\
\hline Muscle Weight (g) & 0.330 & 0.362 & 0.387 & 0.435 & $Y=0.327+0.003 x$ & 0.98 \\
\hline \multicolumn{7}{|l|}{ color $($ CIE L*a*b*) } \\
\hline $\mathrm{L}$ & 45.37 & 44.16 & 43.57 & 47.77 & $\mathrm{Y}=45.22$ & ns \\
\hline $\mathrm{a}$ & 8.40 & 8.35 & 7.19 & 7.40 & $\mathrm{Y}=8.45-0.04 \mathrm{x}$ & 0.72 \\
\hline $\mathrm{b}$ & 12.28 & 12.56 & 10.21 & 11.79 & $\mathrm{Y}=11.71$ & ns \\
\hline \multicolumn{7}{|l|}{ color $($ CIE L*c*h*) } \\
\hline $\mathrm{L}$ & 45.37 & 44.16 & 43.57 & 47.77 & $Y=45.57-0.33 x+0.013 x^{2}$ & 0.91 \\
\hline $\mathrm{c}$ & 14.97 & 13.87 & 12.19 & 13.58 & $\mathrm{Y}=13.65$ & ns \\
\hline $\mathrm{h}$ & 55.59 & 54.91 & 54.15 & 59.75 & $Y=55.91-0.35 x+0.015 x^{2}$ & 0.88 \\
\hline $\mathrm{aW}$ & 1.00 & 1.00 & 1.00 & 0.99 & $\mathrm{Y}=0.99$ & ns \\
\hline WRC & 0.51 & 0.54 & 0.52 & 0.52 & $\mathrm{Y}=0.52$ & ns \\
\hline $\mathrm{SF}(\mathrm{N})$ & 2.82 & 3.36 & 3.56 & 4.96 & $Y=2.68+0.006 x^{2}$ & 0.87 \\
\hline $\mathrm{SF}(\mathrm{Kgf} / \mathrm{s})$ & 0.27 & 0.34 & 0.36 & 0.50 & $Y=0.23+0.006 x^{2}$ & 0.88 \\
\hline WLC & 1.61 & 1.64 & 1.60 & 1.41 & $\mathrm{Y}=1.56$ & ns \\
\hline $\mathrm{pH}$ & 5.94 & 5.86 & 5.86 & 6.04 & $Y=5.94-0.02 x^{2}$ & 0.97 \\
\hline $\mathrm{H}(\%)$ & 73.19 & 74.41 & 73.89 & 73.48 & $Y=73.74$ & ns \\
\hline $\mathrm{CD}(\%)$ & 19.53 & 19.88 & 18.30 & 21.00 & $\mathrm{Y}=19.67$ & ns \\
\hline MM (\%) & 0.97 & 0.91 & 0.96 & 1.04 & $Y=0.97$ & ns \\
\hline TL $(\%)$ & 0.12 & 0.15 & 0.20 & 0.19 & $Y=2.23+0.24 x-0.006 x^{2}$ & 0.86 \\
\hline ENER $(\mathrm{kcal} / \mathrm{kg})$ & 0.128 & 0.153 & 0.204 & 0.195 & $\mathrm{Y}=0.170$ & ns \\
\hline
\end{tabular}

CIE: International Commission on Illumination; L* - luminosity; $\mathrm{a}^{*}$ - red; $\mathrm{b}^{*}$ - yellow; $\mathrm{c}^{*}$ : chroma and $\mathrm{h}^{*}$ - degree of hue. aW: water activity; WRC: water retention capacity; $\mathrm{SF}(\mathrm{N})$ : shear force in Newton; SF(kgf/s): shear force in Kgf; LWC: weight loss in cooking; H: humidity; CD: crude protein; MM: mineral matter; TL: total lipids; ENER: energy.

Source: Elaboration of the authors.

According to Bressan, Prado and Pérez (2001), $\mathrm{pH}$ influences the capacity to retain water, loss of weight in cooking and shear force, as well as sensorial properties such as tenderness, juiciness, flavor, aroma and color. The $\mathrm{pH}$ values found indicate that meat from lambs fed passion fruit peel were 
good quality, since values over 6.2 would indicate that the meat was ready for immediate consumption or at a critical limit for consumption. This result can be explained by the fact that the muscles were analyzed after 30 days of freeze storage.

Water activity, water retention capacity and weight loss in cooking were not different in the meat of lambs fed different proportions of passion fruit peel added to elephant grass silage, with average values of $0.99,0.52$ and 1.56 respectively.

Considering the average water activity results in this experiment, it can be affirmed that the meat analyzed was prone to microorganism attack, because microbial growth and metabolism require the presence of available water. Usually, high water activity is related with increased $\mathrm{pH}$, that is, far from the isoelectric point, inhibiting meat or meat product dehydration.

According to Martins (2006), water activity is an indication of availability for use in chemical reactions and microbial growth, and water bound to macromolecules by physical forces is not available to chemical reactions, and thus cannot be used by microorganisms. Silva (2000) explains that water activity in food is defined as the relationship between the water vapor pressure in the food substrate $(\mathrm{P})$ and the solvent's water vapor pressure (P0) at the same temperature, or aW $=\mathrm{P} / \mathrm{P} 0$.

For every $1 \%$ addition of dry passion fruit peel there was an increase of 0,006 in shear force, that is, the meat from lambs fed $30 \%$ passion fruit peel was firmer than others, but at the value of 0.50 $\mathrm{kgf} / \mathrm{s}$, the muscle was extremely tender and far from the average texture values found by França (2010) in the muscles longissimus lumborum and semimembranosus of Santa Inês lambs supplemented with monensin and slaughtered at a body weight of $45 \mathrm{~kg}$ : 3.64 and $4.39 \mathrm{kgf} / \mathrm{s}$, respectively.

Boleman et al. (1997) classified meat texture as very tender (2.3 to $3.6 \mathrm{~kg})$, moderately tender (4.1 to $5.4 \mathrm{~kg}$ ) and slightly tender (5.9 to $7.2 \mathrm{~kg}$ ). By Boleman's classification, the results of the present study do not fall into the tenderness classification criteria, however, since the results found are below $2.3 \mathrm{~kg}$, they may lead to classifying the longissimus lumborum in this experiment as extremely tender.

It is noteworthy that the shear force found in literature is very different, because the objectives of sheep meat quality researchers are scarce, specific and different. Such variation may occur also due to different protocols employed in shear force analyses, since the methodology has not been standardized.

The meat from sheep fed other fodder and from sheep fed dried passion fruit peel had the same luminosity $\left(\mathrm{L}^{*}\right)$ and yellow hue $\left(\mathrm{b}^{*}\right)$, with average values of 45.2 and 11.7, respectively. This is confirmed by the observation of values for red (a*), which displayed decreasing linear behavior, therefore, treatments with 0 and $10 \%$ passion fruit peel yielded redder meat hues than others. In the CIE L* $\mathrm{c}^{*} \mathrm{~h} *$ evaluation, a difference was observed between treatments where treatments with 10 and $20 \%$ passion fruit peel resulted in lower values with darker meat.

Leão et al. (2012) when evaluating confined lambs fed diets containing sugarcane with a forage:concentrate ratio of 40:60, observed that the color of the longissimus lumborum and triceps brachii muscles did not change, similarly to the results of the present study. The same was observed by Arquimède et al. (2008) when studying the effect of increasing levels of concentrate $(0.150,300$ and $600 \mathrm{~g}$ ) in the diets of confined lambs, also verified that the diets did not influence the meat color of the longissimus lumborum muscle.

When evaluating subjective and instrumental characteristics of sheep meat, Rota et al. (2006) found $L^{*}$ (luminosity) values between 39.12 and 42.35 , but the meat of lambs slaughtered at 210 days had higher $\mathrm{L}^{*}$ values, resulting in more brilliance and differing from the meat of animals slaughtered at 360 days.

The percent composition of muscle longissimus lumborum regarding crude protein and mineral 
matter content was not influenced by the addition of passion fruit peel to the elephant grass silage, however, total lipids with values at $0.12 ; 0.15 ; 0.20$ and $0.19 \%$ for treatments with $0 ; 10 ; 20$ and $30 \%$ of passion fruit peel addition had a quadratic behavior with the maximum point at $20 \%$ supply of passion fruit peel. Nevertheless, although lipid content increased in meat with added passion fruit peel, the values found are low without compromising meat quality.

Zeola et al. (2004) found the following contents in semimenbranosus muscle from Morada Nova sheep fed different concentrate contents: between $75.43 \%$ and $75.75 \%$ humidity, $19.64 \%$ and $20.61 \%$ protein and 2.14 and 2.40 fat, having verified an increase in protein and fat when the level of concentrates of the diet is increased. The data presented put in evidence the effect of feed in the chemical composition of sheep's meat, however, Teixeira (2000) clarifies that the chemical composition of meat can be influenced by genotype, sex, feed, age and weight. These factors affect the degree and location of tissue deposition, being age and nutrition the most important, and fatty tissue the one that varies the most.

Zeola, Silva Sobrinho and Manzi (2011) determined the percent composition of meat from lambs reared in organic and conventional production systems and verified that in the longissimus dorsi muscle, only mineral matter was influenced and displayed lower value in the organic system (1.02) when compared to the conventional system $(1.09 \%)$. There was no influence from the production systems for dry matter, protein and fat contents.

Nutrition can change the chemical composition of meat by nutrient partition in the diet. Leão et al. (2012) evaluated the nutritional characteristics of the meat from lambs terminated with diets containing sugarcane or corn silage and two levels of concentrate, and observed that the meat from lambs fed corn silage had a higher ether extract content $(3.97 \%)$ when compared with lambs fed diets containing sugarcane $(3.71 \%)$, and attributes this to the concentrations of this nutrient in the diets, since the concentration of ether extract in sugarcane diets was lower $(1.58 \%)$ than that of corn silage $(3.12 \%)$. However, the meat from lambs fed diets with more concentrate had a higher ether extract content $(4.02 \%)$ when compared with lambs fed diets with more forage $(3,68 \%)$, accentuating the higher fat content of the meat as a result of more concentrated nutrition.

The scales that determine meat color were correlated with longissimus lumborum percent composition, taking into consideration only the diets containing silage to which passion fruit peel was added (Table 4).

CIEL*c*h* scale values were calculated using the CIEL*a*b* scale values. The $\mathrm{c}^{*}$ value (chroma) and the $h^{*}$ value (hue angle) were calculated using $a *$ and $b^{*}$ of the CIEL*a*b* scale, however, the CIEL* ${ }^{*} \mathrm{~h} *$ scale indicates the laid out color space and can sometimes better identify meat color or supplement the identification. 
Table 4. Correlation between color scales and the percent composition of longissimus lumborum of Santa Inês lambs fed elephant grass silages containing dried passion fruit peel.

\begin{tabular}{lccccc}
\hline \multicolumn{1}{c}{ Color scales } & H (\%) & CD (\%) & MM (\%) & TL (\%) & ENER (Kcal/kg) \\
\hline L.lumborum (kg) & -0.46 & 0.04 & -0.14 & 0.22 & -0.35 \\
L* & -0.44 & $0.58^{*}$ & 0.32 & 0.09 & 0.51 \\
$\mathrm{a}^{*}$ & -0.44 & 0.01 & -0.01 & -0.37 & 0.07 \\
$\mathrm{~b}^{*}$ & -0.18 & 0.29 & 0.23 & -0.07 & 0.30 \\
$\mathrm{c}^{*}$ & -0.17 & 0.09 & 0.25 & 0.09 & 0.23 \\
$\mathrm{~h}^{*}$ & 0.19 & 0.48 & 0.14 & 0.27 & 0.17 \\
\hline
\end{tabular}

L.lumborum: longissimus lomborum; $\mathrm{L}^{*}=$ luminosity from 0 (black) to 100 (white); $\mathrm{a}^{*}=$ color intensity from green to red $\mathrm{b}^{*}=$ color intensity from blue to yellow; $\mathrm{c}^{*}=$ chroma; $\mathrm{h}^{*}=$ hue angle; H: humidity; CD: crude protein; MM: mineral matter; TL: total lipids; ENER: energy.

Source: Elaboration of the authors.

The color of meat from lambs fed silage containing up to $30 \%$ dried passion fruit peel did not have any correlation with mineral, total lipids and energy contents, except for luminosity, which had a positive correlation with the quantity of meat found in longissimus lumborum. However, the red value $\left(\mathrm{a}^{*}\right)$, which is related to myoglobin content, had values that varied from 7.2 (30\% passion fruit peel) to 9.2 (10\% passion fruit peel) (Table 2), implying in saying that the addition of passion fruit peel to the diet has rendered the meat from Santa Inês lambs less intensely red, however, this color variable did not correlate with any nutrient proximal of longissimus lumborum (Table 4), indicating that under the conditions of the present experiment, there is no association between red hue and percent composition, that is to say, other factors probably have more interference on meat nutrients than color, that is to say, this quality parameter is more a consequence of ante and postmortem treatments and changes, than nutrition type.

Physicochemical parameters were correlated with the percent composition of longissimus lumborum, considering only those diets containing passion fruit peel silage (Table 5). Shear force was observed to be the parameter presenting positive correlation with meat protein $(0.65)$, mineral matter (0.62) and energy (0.52).

Table 5. Correlation between physicochemical parameters and percent composition of longissimus lumborum of Santa Inês lambs fed elephant grass silages containing dried passion fruit peel

\begin{tabular}{lcccccc}
\hline $\begin{array}{c}\text { Physicochemical } \\
\text { Parameters }\end{array}$ & $\begin{array}{c}\text { L.lumborum } \\
\mathbf{( k g )}\end{array}$ & $\begin{array}{c}\text { H } \\
\mathbf{( \% )}\end{array}$ & $\begin{array}{c}\text { CD } \\
\mathbf{( \% )}\end{array}$ & $\begin{array}{c}\text { MM } \\
\mathbf{( \% )}\end{array}$ & $\begin{array}{c}\text { TL } \\
\mathbf{( \% )}\end{array}$ & $\begin{array}{c}\text { ENER } \\
(\mathbf{K c a l} / \mathbf{k g})\end{array}$ \\
\hline$a W$ & -0.16 & 0.04 & 0.05 & -0.45 & $-0.58^{*}$ & -0.32 \\
WRC & -0.12 & 0.59 & 0.35 & -0.46 & -0.47 & -0.21 \\
SF $(\mathrm{kgf} / \mathrm{s})$ & 0.15 & -0.32 & $0.65^{*}$ & $0.62^{*}$ & $0.55^{*}$ & $0.52^{*}$ \\
WLC & $-0.62^{*}$ & -0.29 & 0.18 & -0.00 & 0.07 & 0.18 \\
pH & 0.18 & -0.28 & 0.14 & $0.73^{*}$ & $0.65^{*}$ & 0.37 \\
\hline
\end{tabular}

aW: water activity; WRC: water retention capacity; SF: shear force; LWC: weight loss in cooking;

Source: Elaboration of the authors.

Increasing or decreasing shear force for sheep meat can occur due to interactions between different rates of collagen deposition and fat interspersed in muscle Sañudo (2002). However, fat quantity is 
directly influenced by type of feed and therefore, so is meat tenderness, which is one of the most evaluated parameters to guarantee the product sells, since more tender meat is usually more valued and consequently, more consumed.

Weight loss in cooking also had negative correlation (-0.62) with the weight of longissimus lumborum from Santa Inês lambs fed grass elephant silages containing dried passion fruit peel, whereas $\mathrm{pH}$ was high and positively correlated with mineral matter content $(0,73 *)$ and little correlated with total lipid content $(0,65)$. This confirms that the nutritional level or the type of feed is related with fat content of the carcass, moreover in animals fed high quantities of concentrate or diets planned for confinement, which influence meat quality factors such as $\mathrm{pH}$, color, tenderness, weight loss in cooking and water activity.

Water activity was negatively correlated with total lipid content $\left(-0,58^{*}\right)$, indicating that the more fat content in meat from lambs fed passion fruit peel, decresead their water activity. It is noteworthy that passion fruit peel increased the fatty content of longissimus lumborum when included in the silage diet at $20 \%$. Therefore, since water activity is a more commonly used measure to express the availability of water in feeds, and a value between 0.98 and 0.99 favors microorganism growth, and decreased water activity is satisfactory for meat quality. Silva Júnior (1995), considers water activity below 0.60 to limit microbial growth.

Dry passion fruit peel can be used up to $30 \%$ of the diets of finishing lambs because it does not interfere negatively on meat quality and nutritional parameters. Fernandes et al. (2011) determined qualitative characteristics of the carcass and meat from Santa Inês lambs finishing in confinement and fed diets containing soybeans or protected fat, and observed better performance in heavier animals and carcasses, without interference in meat quality.

\section{Conclusion}

The inclusion of $30 \%$ passion fruit peel in the diet of Santa Inês lambs renders the meat a less intense red, but nevertheless with a good degree of hue, good water retention capacity and adequate shear force and $\mathrm{pH}$, enough to guarantee quality. Protein, minerals and energy content are not changed, but neither do they display values lower than desired by the industry. It is recommended that $30 \%$ passion fruit peel is added to the silage for growing Santa Inês lambs, as it improves the meat quality and nutritional parameters.

\section{Acknowledgement}

To company Necttare Indústria e Comercio de Produtos Alimentícios Ltda.

To research group EPOC- Equipe de Pesquisa em Ovinos e Caprinos.

To Universidade Estadual do Sudoeste da BahiaUesb.

\section{References}

AMASA. Diretrizes para Avaliação Sensorial Cookingand de carne. Carne americana. Science Association, National Stock Live e tábua de cortar carne, Chicago, IL, 1978.

ANDRADE, F. A. O.; AZEVEDO, A. R.; SALES, R. O.; ARRUDA, F. A. V.; SOUZA, P. Z. Consumo de nutrientes por ovinos alimentados com diferentes dietas à base de resíduos da agroindústria. Revista Científica de Produção Animal, Teresina, v. 3, n. 1, p. 68-76, 2001.

ASSOCIATION OFFICIALANALYTICAL CHEMISTS - AOAC. Official methods of analysis of the association of official analytical chemists. 17. ed. Arlington: AOAC Inc., v. 1, v. 2, 2000.

ARQUIMÈDE, H.; PELLONDE, P.; DESPOIS P.; ETIENNE, T.; ALEXANDRE, G. Growth performance and carcass traits of ovin martinik lambs fed various ratios of tropical forage to concentrate under intensive conditions. Small Ruminante Research, Amsterdam, v. 75, n. 2-3, p. 162-170, 2008. 
ASTIZ, C. S. Qualidade da carcaça e da carne ovina e caprina em face ao desenvolvimento da percepção do consumidor. Revista Brasileira de Zootecnia, Viçosa, MG, v. 37, p. 143-160, 2008. Suplemento Especial.

AZZALINI, M.; PONZONI, R. Aspectos modernos de la produción ovina. Montevideo: Universidade de la Republica. Departamento de Publicaciones, 1979. 75 p.

BOLEMAN, S. J.; BOLEMAN, S. L.; MILLER, R. K.; TAYLOR, J. F.; CROSS, H. R.; WHEELER, T. L.; KOOHMARAIE, M.; SHACKELFORD, S. D.; MILLER, M. F.; WEST, R. L.; JOHNSON, D. D.; SAVELL, J. W. Consumer evaluation of beef of known categories of tenderness. Journal of Animal Science, Champaign, v. 75, n. 6, p. 1521-1524, 1997.

BORGES, P. H. R.; AZEVEDO, A. R.; SALES, R. O.; ARRUDA, F. A. V.; ALVES, A. A. Desempenho de ovinos alimentados com diferentes níveis de pseudofruto seco do cajueiro. Revista Cientifica de Produção Animal, Teresina, v. 3, n. 6, p. 24-34, 2004.

BRASIL. Ministério da Agricultura. Regulamento da inspeção industrial e sanitária de produtos de origem animal. Brasília, DF, 1997.

BRESSAN, M. C.; PRADO, O. V.; PÉREZ, J. R. O. Efeito do peso ao abate de cordeiros Santa Inês e Bergamácia sobre as características físico-químicas da carne. Ciência e Tecnologia de Alimentos, Lavras, MG, v. 21, n. 3, p. 293-303, 2001.

CRUZ, B. C. C.; SANTOS-CRUZ, C. L.; PIRES, A. J. V.; BASTOS, M. P. V.; SANTOS, S.; ROCHA, J. B. Silagens de elephant grass com diferentes proporções de casca desidratada de maracujá em dietas de cordeiros Santa Inês. Revista Brasileira de Saúde Produção Animal, Salvador, v. 12, n. 1, p. 107-116, 2011.

DIAZ, M. T.; VELASCO, S.; CAÑEQUE, V.; LAUSURICA, S.; RUIZ DE HUIDOBRO, F.; PÉREZ, C.; GONZÁlEZ, J.; MANZANARES, C. Use of concentrate or pasture for fattening lambs and its effect on carcass and meat quality. Small Ruminant Research, Amesterdam, v. 43, n. 3, p. 257-268, 2002.

FERNANDES, A. R. M.; ORRICO JUNIOR, M. A. P.; ORRICO, A. C. A.; VARGAS JUNIOR, F. M.; OLIVEIRA, A. B. M. Desempenho e características qualitativas da carcaça e da carne de cordeiros terminados em confinamento alimentados com dietas contendo soja grão ou gordura protegida. Revista Brasileira de Zootecnia, Viçosa, v. 40, n. 8, p. 1882-1829, 2011.

FRANÇA, P. Uso de ionóforos na alimentação de cordeiros Santa Inês para produção de carne. 2010. Tese (Doutorado em Zootecnia) - Universidade Federal de Lavras, Lavras.
FURUSHO, I. F.; PÉREZ, J. R. O.; LIMA, G. F. C. Desempenho de cordeiros Santa Inês, terminados em confinamento, com dieta contendo pedúnculo do caju. In: REUNIÃO ANUAL DA SOCIEDADE BRASILEIRA DE ZOOTECNIA, 34., 1997, Juiz de Fora. Anais... Juiz de Fora: Sociedade Brasileira de Zootecnia, 1997. p. 385-87.

GALLO, S. B.; SIQUEIRA, E. R.; DELGADO, R. F.; SILVA, M. D. P.; ROSA, G. T. Influence of feeding regime and finishing system on lamb muscle fiber and meat quality. Revista Brasileira de Zootecnia, Viçosa, MG, v. 38, n. 11, p. 2204-2210, 2009.

HOPKINS, D. L.; HALL, D. G.; CHANNON, H. A. Meat quality of mixed sex lambs grazing pasture and supplemented with, roughage, oats or oats and sunflower meal. Meat Science, Amesterdam, v. 59, n. 3, p. 277-283, 2001.

INSTITUTO ADOLFO LUTZ - IAL. Normas analiticas do instituto adolfo lutz: métodos químicos e físicos para análise de alimentos. 3. ed. São Paulo: IMESP, 1985. v. 1, p. 21-22.

JOHNSON, M. H.; BIDNER, T. D.; MCMILLIN, K. W.; DUGAS, S. M.; HEMBR, Y. F. G. The effect of three temperature conditioning treatments and subcutaneous fat removal on lamb quality. Journal of Animal Science, Champaign, v. 67, n. 1, p. 2309-2315, 1989.

LEÃO, A. G.; SILVA SOBRINHO, A. G.; MORENO, G. M. B.; SOUZA, H. B. A.; PEREZ, H. L.; LOUREIRO, C. M. B. Características nutricionais da carne de cordeiros terminados com dietas contendo cana-de-açúcar ou silagem de milho e dois níveis de concentrado. Revista Brasileira de Zootecnia, Viçosa, v. 41, n. 5, p. 12531262, 2012.

LOUSADA JUNIOR, J. E.; COSTA, J. M. C.; NEIVA, J. N. M.; RODRIGUEZ, N. M. Caracterização físicoquímica de subprodutos obtidos do processamento de frutas tropicais visando seu aproveitamento na alimentação animal. Revista Ciência Agronômica, Pernambuco, v. 37, n. 1, p. 70-76, 2006.

MADRUGA, M. S.; SOUSA, W. H.; ROSALES, M. D.; CUNHA, M. G. G.; RAMOS, J. L. F. Qualidade da carne de cordeiros Santa Inês terminados com diferentes dietas. Revista Brasileira de Zootecnia, Viçosa, v. 34, n. 1, p. 309-315, 2005.

MARTINS, R. Produção de embutidos crus-curados - salame. Rio de Janeiro: REDET, 2006. 24 p. (Dossiê técnico).

NAKAMURA, M.; KATOH, K. Influence of thawing on several proprieties of rabbit meat. Bulletim of Ishikawa Prefecture College of Agriculture, Ishikawa, v. 11, p. 4549, 1985. 
NEIVA, J. N. M.; NUNES, F. C. S.; CANDIDO, M. J. D.; RODRIGUES, N. M.; LOBOS, R. N. B. Valor nutritivo de silagens de elephant grass enriquecidas com subproduto do processamento do maracujá. Revista Brasileira de Zootecnia, Viçosa, MG, v. 35, n. 4, p. 18451851, 2006.

NATIONAL RESEARCH COUNCIL - NRC. Nutrient requirements of small ruminants. Washington, D.C.: National Academy Press, 2006. 362 p.

PINHEIRO, R. S. B.; JORGE, A. M.; SOUZA, H. B. A.; BOIAGO, M. M. Coloração da gordura e qualidade da carne de ovelhas de descarte abatidas em distintos estágios fisiológicos. Arquivos Brasileiro de Medicina Veterinária e Zootecnia, Belo Horizonte, v. 62, n. 2, p. 468-474, 2010.

ROTA, E. L.; OSÓRIO, M. T. M.; OSÓRIO, J. C. S.; OLIVEIRA, M. T. M.; WIEGAND, M. M.; MENDONÇA, G.; ESTEVES, R. M.; GONÇALVES, M. Influência da castração e da idade de abate sobre as características subjetivas e instrumentais da carne de cordeiros Corriedale. Revista Brasileira de Zootecnia, Viçosa, v. 35, n. 6, p. 2397-2405, 2006.

SANTOS, C. L. Estudo do crescimento e da composição química dos cortes da carcaça de cordeiros Santa Inês e Bergamácia. 2002. Tese (Doutorado em Zootecnia) Universidade Federal de Lavras, Lavras.

SAÑUDO, C. Factors affecting carcass and meat quality in lambs. In: REUNIÃO ANUAL DA SOCIEDADE BRASILEIRA DE ZOOTECNIA, 39., 2002, Recife. Anais... Recife: SBZ, 2002. p. 434-455.

SAS Institute. SAS system for windows. Version 8.0. Cary: SAS Institute Inc., 2001. 2 CD-ROM.
SILVA JÚNIOR, E. A. Manual de controle higiênicosanitário em serviço de alimentação. São Paulo: Livraria Varela, 1995. 223 p.

SILVA, D. J. Análise de alimentos: métodos químicos e biológicos. Viçosa: UFV, Imprensa Universitária, 1981. $166 \mathrm{p}$.

SILVA, J. A. Tópicos da tecnologia de alimentos. São Paulo: Varela, 2000. 231 p.

TEIXEIRA, J. C. Composição corporal e exigências nutricionais de energia e proteina de cordeiros Bergamácia dos 35 aos $45 \mathrm{~kg}$ de peso vivo. 2000. Dissertação (Mestrado em Zootecnia) - Universidade Federal de Lavras, Lavras.

TONETTO, C. J.; PIRES, C. C.; MÜLLER, L.; ROCHA, M. G.; SILVA, J. H. S.; FRESCURA, R. B.; KIPPERT JUNIOR, C. Rendimentos de cortes da carcaça, características da carne e componentes do peso vivo em cordeiros terminados em três sistemas de alimentação. Revista Brasileira de. Zootecnia, Viçosa, MG, v. 33, n. 1, p. 234-241, 2004.

ZEOLA, N. M. B. L.; SILVA SOBRINHO, A. G.; GONZAGA NETO, S. MARQUES, C. A. T. Composição centesimal da carne de cordeiros submetidos a dietas com diferentes teores de concentrado. Ciência Rural, Santa Maria, v. 34, n. 1, p. 253-257, 2004.

ZEOLA, N. M. B. L.; SILVA SOBRINHO, A. G.; MANZI, G. M. Composição regional e centesimal da carcaça de cordeiros criados nos sistemas de produção orgânico e convencional. Revista Brasileira de Zootecnia, Viçosa, MG, v. 40, n. 12, p. 2963-2970, 2011. 